\title{
Regional Sediment Budgets for the Haleiwa Region, Oahu, Hawaii
}

\section{US Army Corps} of Engineers $\mathbf{B}_{\circledast}$

\author{
by Jessica H. Podoski
}

PURPOSE: This Coastal and Hydraulics Engineering Technical Note (CHETN) reviews the development of conceptual regional sediment budgets (RSB) for the Haleiwa Region on the island of Oahu, Hawaii, as part of the Hawaii Regional Sediment Management (RSM) Program. This document discusses the methodology used for determining volume change rates as well as numerical models utilized, including the Particle Tracking Model (PTM), in support of identifying sediment pathways in the region. The results of these investigations were used to create the pre- (1922-1948) and post-Haleiwa Harbor (1988-2006) sediment budgets for the Haleiwa Region using the Sediment Budget Analysis System (SBAS) software.

BACKGROUND: Regional Sediment Management refers to the effective use of littoral, estuarine, and riverine sediment resources in an environmentally sensitive and economically efficient manner. RSM was officially implemented at the US Army Corps of Engineer (USACE) Honolulu District (POH), Honolulu, Hawaii, in February 2004. Honolulu District's overall RSM strategy is to investigate RSM opportunities along all regions in Hawaii. Conceptual regional sediment budgets have been developed in various regions throughout the Hawaiian Islands (Figure 1) to gain a general understanding of the control that morphology and coastal processes have on sediment pathways and transport volumes. In the Southeast Oahu Region, Mokapu Point to Makapuu Point RSB investigations facilitated the discovery that the net sediment transport direction at Wailea Point is to the north (not to the south as previously suspected). In the Diamond Head to Pearl Harbor Region of Oahu, it was found that the annual transport rates (either accretive or erosive) in the six littoral cells comprising the region are generally fewer than 2,000 cubic yards per year (cu yd/yr). In Kauai's Kekaha Region, a littoral sink was identified northwest of Kikiaola Light Draft Harbor at which point the annual sediment transport rate in either direction is nearly zero. The RSB for the Kahului Region of Maui indicates that approximately 11,000 cu yd of sand erode from the Kanaha littoral cell annually. Development of the RSBs for the Haleiwa Region was equally as enlightening as previous investigations conducted throughout the state.

Honolulu District's RSM focus in Fiscal Year 2013 was the Haleiwa Region on the north shore of Oahu. Figure 2 shows the littoral cells that comprise the region. From left to right in the figure, these sub-regions are (a) Kaiaka Beach, (b) Alii Beach, (c) Haleiwa Small Boat Harbor (HSBH), (d) Haleiwa Beach Park (HBP), and (e) Puaena Point Beach. Both HSBH and the Haleiwa Beach Restoration Project (fronting HBP) are federally authorized projects and were constructed in the 1960s. The general navigation features at HSBH consist of (a) an entrance channel (740 feet (ft) long, 100-120 ft wide, $12 \mathrm{ft}$ deep), (b) a revetted mole (1,310 ft long), (c) a stub breakwater ( $80 \mathrm{ft}$ long), and (d) a wave absorber (140 ft long). The outer breakwater, approximately $840 \mathrm{ft}$ long, was constructed by the State of Hawaii. The non-federal sponsor for the harbor is the State of Hawaii, Department of Land and Natural Resources, Division of Boating and Ocean Recreation. Approximately $11,000 \mathrm{cu}$ yd of sediment have been 
ERDC/CHL CHETN-XIV-38

June 2014

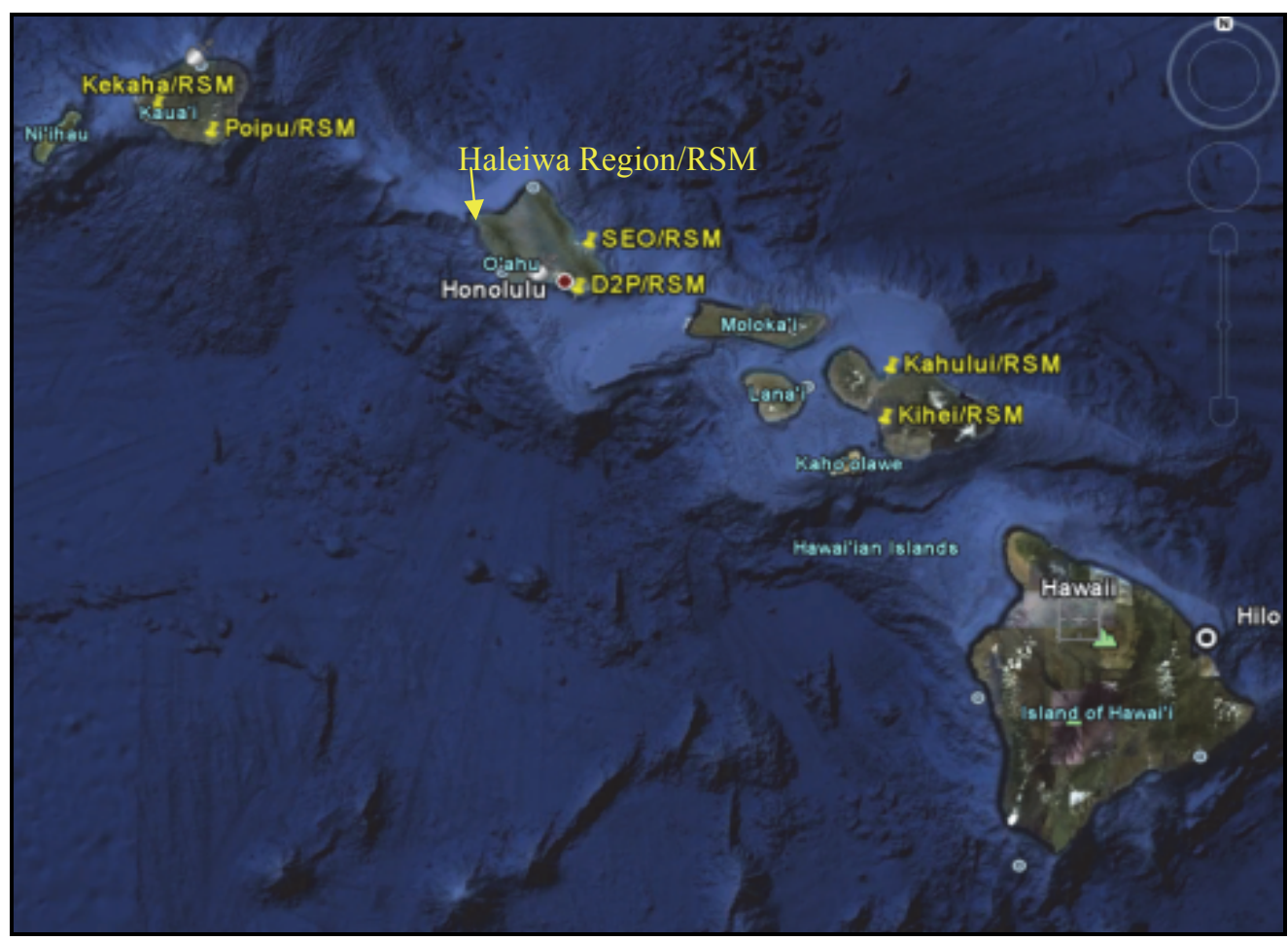

Figure 1. Hawaiian Islands showing existing Hawaii RSM regions, including Haleiwa Region.

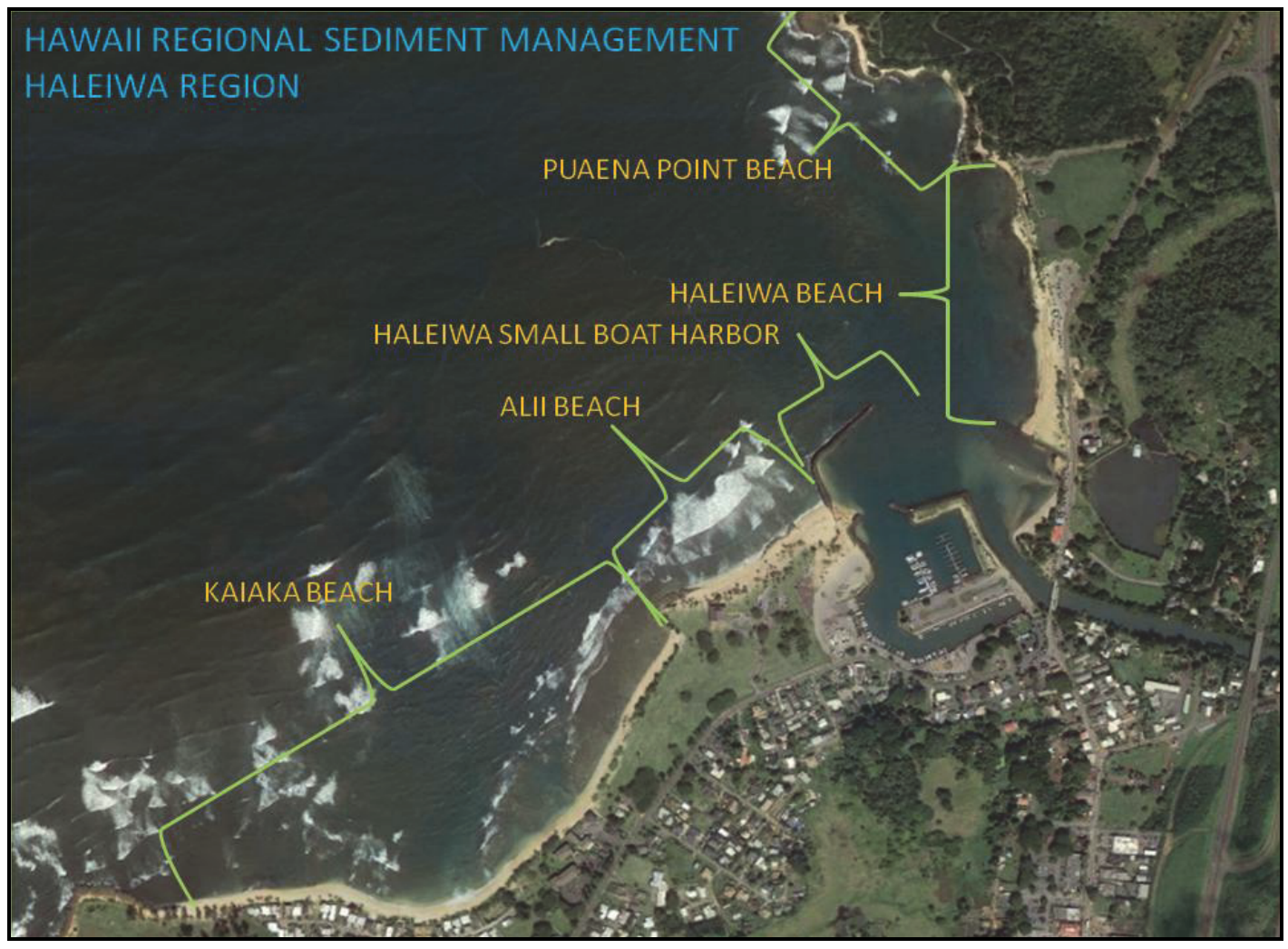

Figure 2. Littoral cells that comprise the Haleiwa Region. 
dredged from the harbor since 1999. The Haleiwa Beach Restoration Project consists of (a) a sand beach (1,600 ft long and 140-265 ft wide), (b) an offshore breakwater (160 ft long), and (c) a groin (500 ft long) which defines the southern limit of the beach improvements. The nonfederal sponsor for the beach restoration project is the State of Hawaii, Department of Transportation. Construction of the beach restoration project was completed in April 1965 and repaired under the authority of Public Law 84-99 in 1978. Approximately 50,000 cu yd of sand were placed within the project limits as part of initial construction and the emergency repair. The project authorization states that the non-federal sponsor is responsible for ongoing maintenance of the project and that USACE may conduct emergency repairs to the project in accordance with Public Law 84-99.

APPROACH: Shoreline change for the region was quantified by the US Geological Survey (USGS) in their report titled National Assessment of Shoreline Change: Historical Shoreline Change in the Hawaiian Islands (Fletcher et al. 2012). The USACE Coastal Inlet Research Program (CIRP) Coastal Modeling System (CMS) numerical models CMS-WAVE and CMSFLOW (Sanchez et al. 2011) were implemented to simulate wave transformation and water circulation within the region. Prevailing (trade wind) and predominant (northwest swell) wind and wave conditions were simulated in steering mode to capture the interdependence of waves and currents. Additionally, the CIRP and Dredging Operations and Environmental Research (DOER) Program Particle Tracking Model (PTM) (McDonald et al. 2006) was utilized to identify dominant sediment pathways. Results from the shoreline change analysis and coastal processes modeling were utilized to develop pre- and post-Haleiwa Harbor RSBs.

Shoreline Change Analysis. Shoreline change rates were calculated from long-term and short-term shoreline data. All available shorelines were used for long-term rate calculations. Pre(1928-1949) and post-Haleiwa Harbor (1988-2006) shorelines were used for short-term rate calculations. A minimum of three historical shoreline positions were required when calculating a shoreline change rate with the technique employed by the USGS. For the USGS North Oahu Region, the maximum long-term erosion rate $(-4.3 \pm 2.6 \mathrm{ft} / \mathrm{yr})$ was found at Haleiwa Beach Park along a segment of shoreline landward of the Haleiwa Beach Park breakwater where the beach has been completely lost since at least 2006. This beach has undergone substantial modification throughout its history, including construction of a groin, breakwater, seawall, and two beach nourishment projects (Hwang 1981; Sea Engineering, Inc. 1988).

Data utilized in the USGS shoreline change analysis were also available in tabular as well as Geographic Information System formats. Figures 3 and 4 are graphs of the USGS shoreline data for 1928-1949, and 1988-2006, respectively. Figure 3 indicates the relative stability of the region's shorelines prior to the construction of the federally authorized harbor and beach erosion control projects. Figure 4 shows continued stability of the shoreline west (left) of the harbor and the erosive nature of the shoreline to the east (right). Utilizing a conversion factor of $0.4 \mathrm{cu}$ yd per square foot ( $\mathrm{cu} \mathrm{yd} / \mathrm{sq} \mathrm{ft}$ ) of shoreline change, the volume change rates for the region were estimated for these same time periods (Figure 5). Based on comparison of the pre- and postHaleiwa Harbor time periods, it appears that the volume change rate has increased along the HBP shoreline from $380 \mathrm{cu} \mathrm{yd/yr} \mathrm{to} 980 \mathrm{cu} \mathrm{yd} / \mathrm{yr}$. 


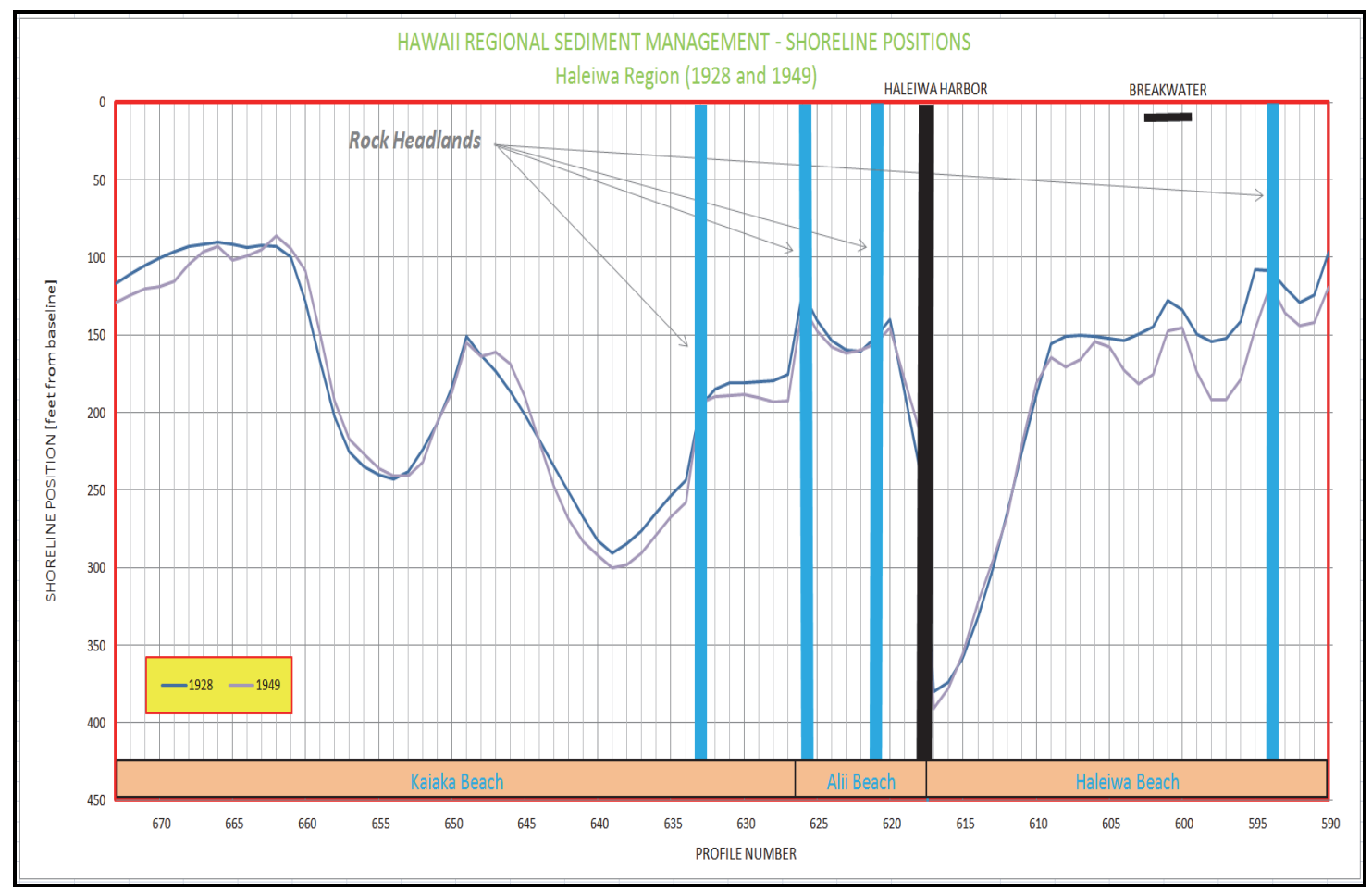

Figure 3. Shoreline changes within the Haleiwa Region from 1928-1949, as determined by US Geological Survey (after Fletcher et al. 2012).

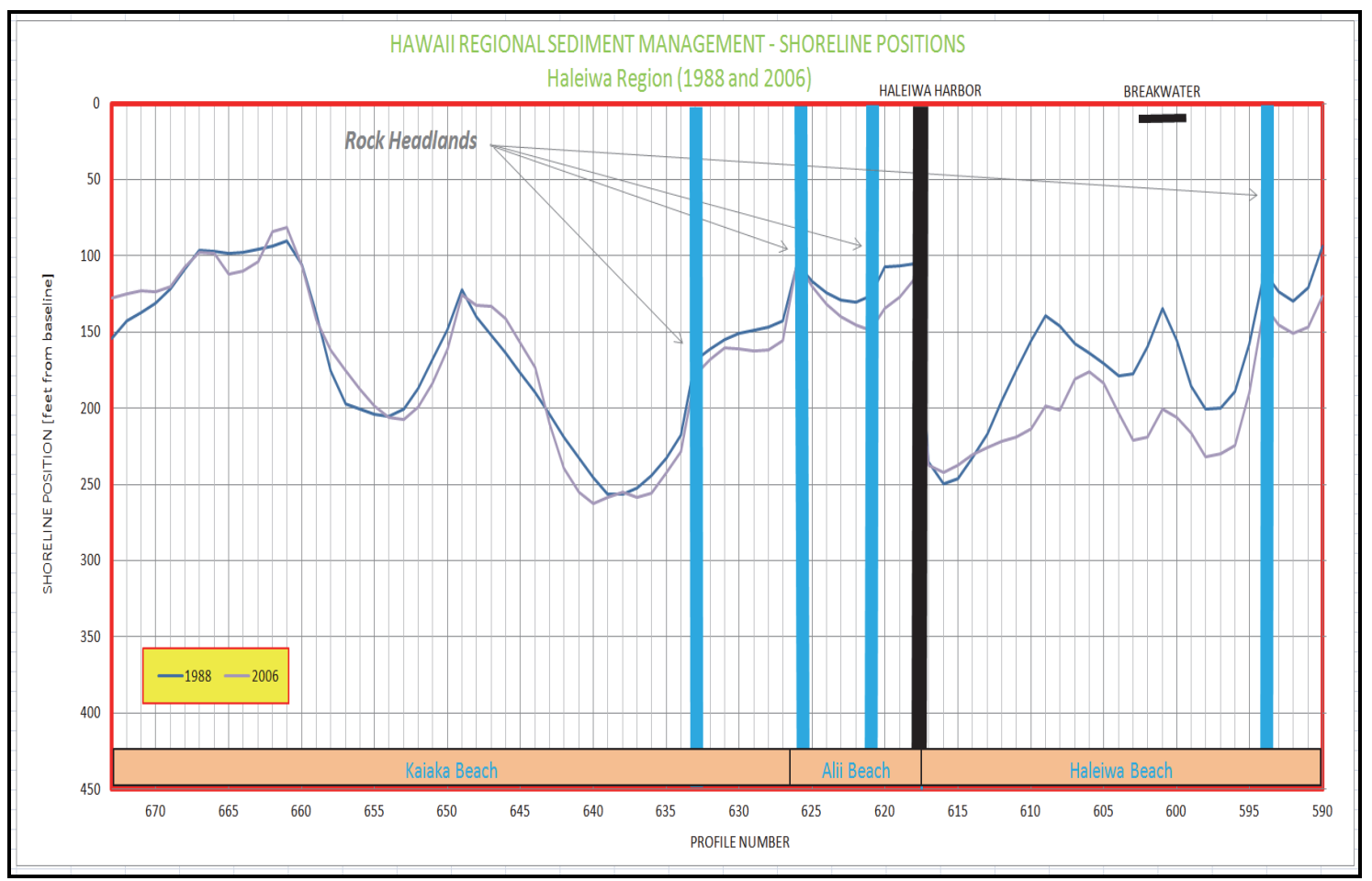

Figure 4. Shoreline changes within the Haleiwa Region from 1988-2006, as determined by US Geological Survey (after Fletcher et al. 2012). 

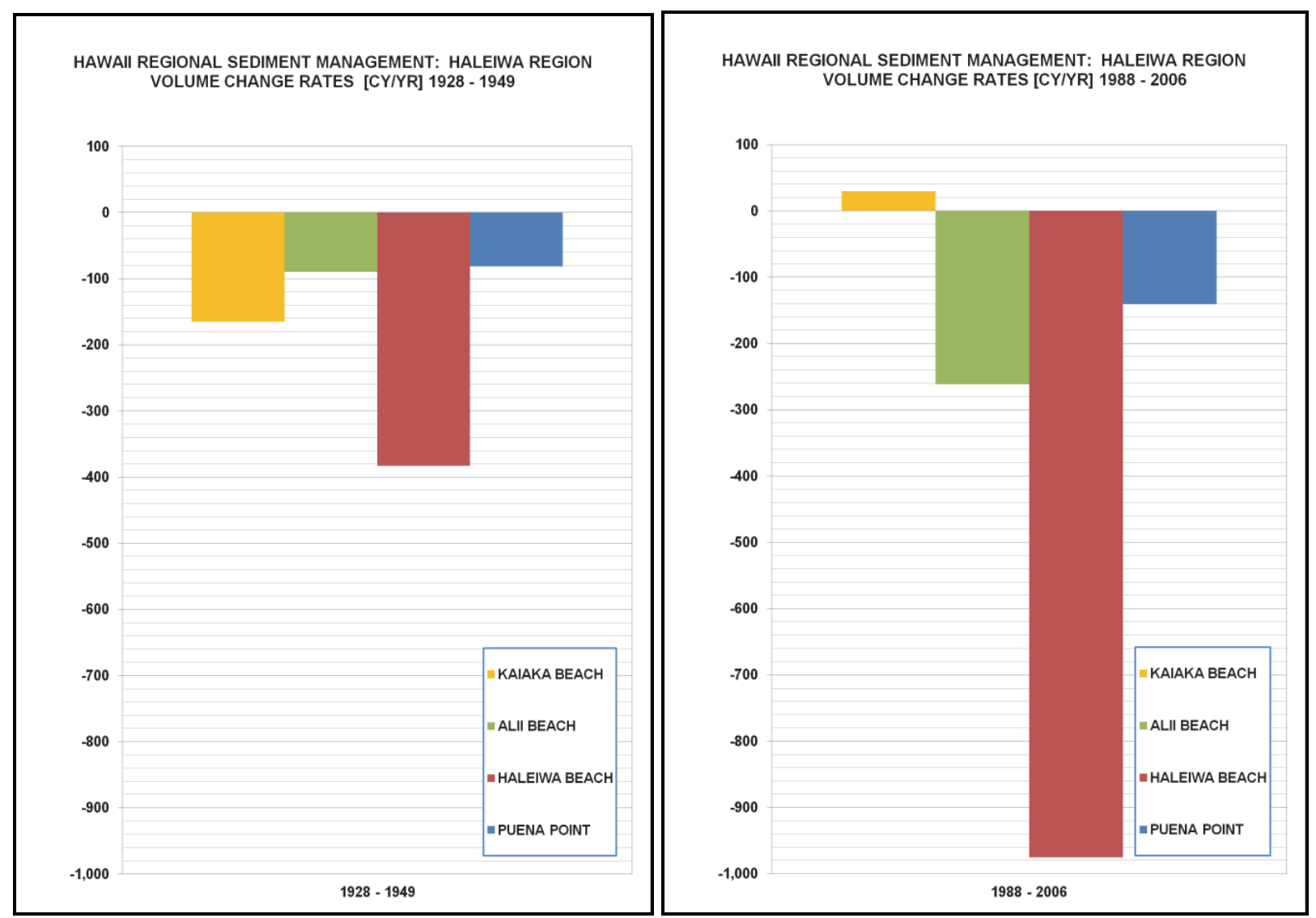

Figure 5. Volume change rates 1928-1949 (left), and 1988-2006 (right) for Haleiwa Region based on shoreline change measured by USGS from 1988 to 2006, utilizing a conversion factor of 0.4 cu yd/sq ft (after Fletcher et al. 2012).

Numerical Modeling. The Haleiwa RSM region, because of its relatively small size and enclosed littoral boundaries, lends itself well to the application of detailed hydrodynamic and wave modeling. The CMS-WAVE and CMS-FLOW wave models were used in steering mode to incorporate the interdependence of tides, currents, wind, and waves. CMS-FLOW water surface elevation was forced using the National Oceanic and Atmospheric Administration (NOAA) subordinate tide station at Haleiwa Harbor, which provides two high tides and two low tides daily (no accurate tidal constituent data is available for this region). Wind input for both the hydrodynamic and wave models (spatially-constant) was taken from Wave Information Study (WIS) Hindcast Station 82509 (Figure 6). Hourly wave forcing data applied at the CMS-WAVE boundary was also supplied by WIS Station 82509. Wave parameters (peak significant wave height $(H s)$, peak spectral period $(T p)$, and direction) were downloaded, and CMS-WAVE was used to generate hourly Texel, MARSEN, and ARSLOE (TMA) wave spectra. The Texel, MARSEN, and ARSLOE field data sets are described in Bouws et al. 1985. 


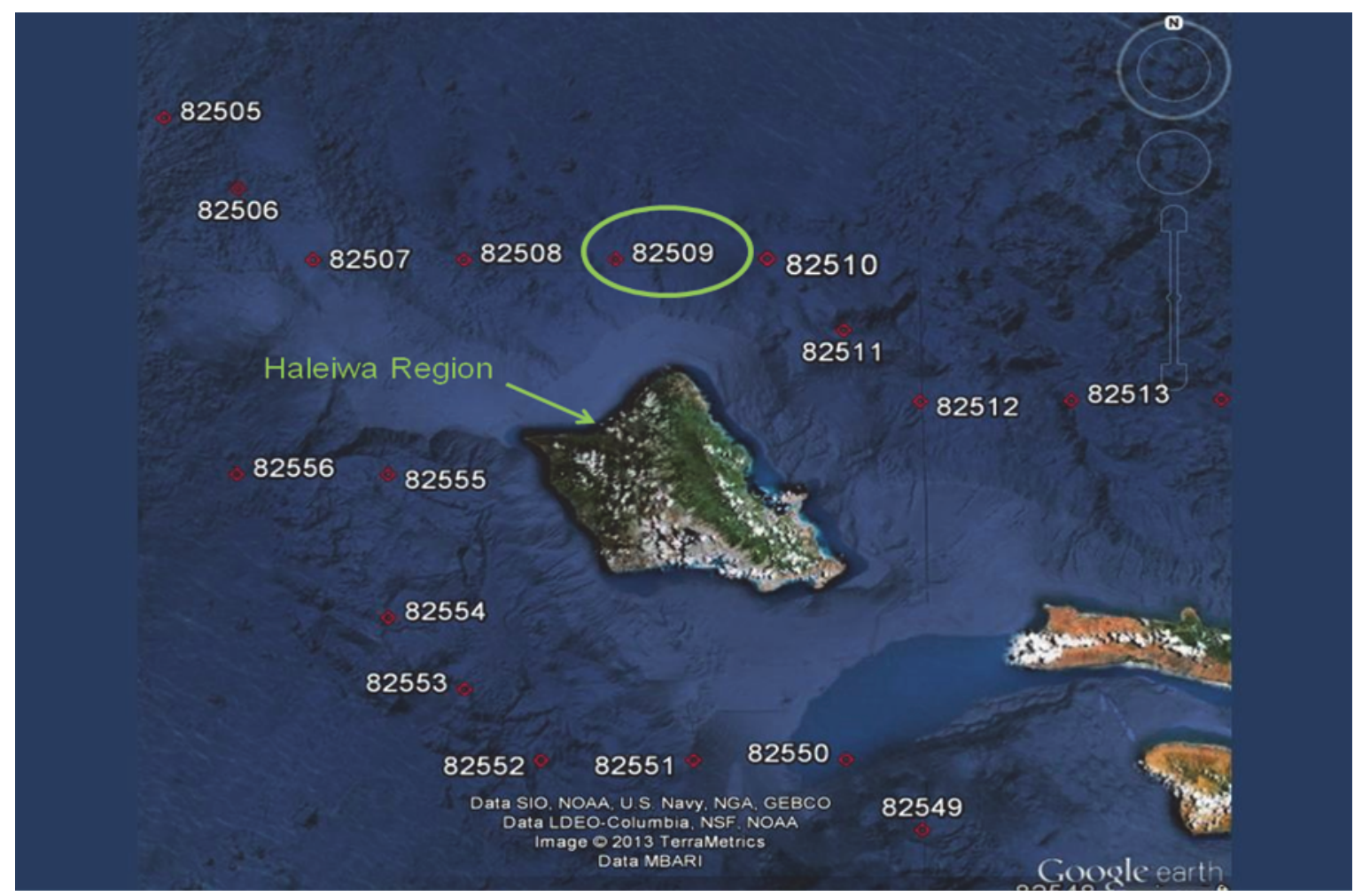

Figure 6. Location of WIS Hindcast Station 82509 relative to the Haleiwa Region.

Grid bathymetry for both models was created using the island-wide bathymetry data developed for the Surge and Wave Island Modeling Studies (conducted by USACE, the University of Hawaii, and Notre Dame University), high-resolution Light Detection and Ranging (LIDAR) data in the nearshore from USACE Joint Airborne LIDAR Bathymetry Technical Center of Expertise, and recent project-condition hydrographic surveys of Haleiwa Harbor. A spatially varying friction factor was applied to both CMS-FLOW and CMS-WAVE to incorporate the effects of increased friction over nearshore reefs on currents and wave breaking. A telescoping grid was utilized for CMS-FLOW, with grid cells ranging from 5 to 320 meters $(\mathrm{m})$ (16 to $1,049 \mathrm{ft}$ ), to incorporate high-resolution input/output in the nearshore areas within the region without requiring excessive computation time. Figure 7 shows the bathymetric contours in the vicinity of the harbor. The primary morphologic features are two relic stream channels, one fronting Kaiaka Beach and the other offshore of the harbor entrance where the mouth of the Anahulu River emptied prior to harbor construction. Also evident in the figure is the extensive V-shaped reef offshore of Alii Beach, ranging from 2.5 to $5 \mathrm{~m}$ (8.2 to $16.4 \mathrm{ft})$ deep. This reef forms a well known surf break called Haleiwa.

Three simulation steering runs were generated based on selected wave and wind hindcast timeseries data of storm events, intended to represent the typical and extreme conditions experienced in the region. The first simulation was a northwest winter swell event with an approximately $15 \mathrm{yr}$ return-period. This event is the second highest wave event in the $31 \mathrm{yr}$ WIS hindcast record, with peak $H s$ of $8.0 \mathrm{~m}(25.9 \mathrm{ft}), T p$ of 21 seconds $(\mathrm{sec})$, and direction $=321^{\circ}(\mathrm{NW})$. The second selected event corresponds to another northwest winter swell event with an approximately 2 yr returnperiod, with peak $H_{s}=5.4 \mathrm{~m}(17.7 \mathrm{ft}), T p=20 \mathrm{sec}$, and direction $=318^{\circ}(\mathrm{NW})$. The third 
simulation was based on a more typical summer trade wind sea event, with peak $H s=2.7 \mathrm{~m}$ $(8.8 \mathrm{ft}), T p=9 \mathrm{sec}$, and direction $=58^{\circ}(\mathrm{NE})$. For this simulation winds were from the ENE $\left(80^{\circ}\right)$ at approximately $10 \mathrm{~m} / \mathrm{sec}(22.3 \mathrm{miles} /$ hour (hr)). Each event was simulated using CMS-WAVE and CMS-FLOW in steering mode for $48 \mathrm{hr}$ based on the available wind, wave, and water level data. All directions above are referenced to true north.

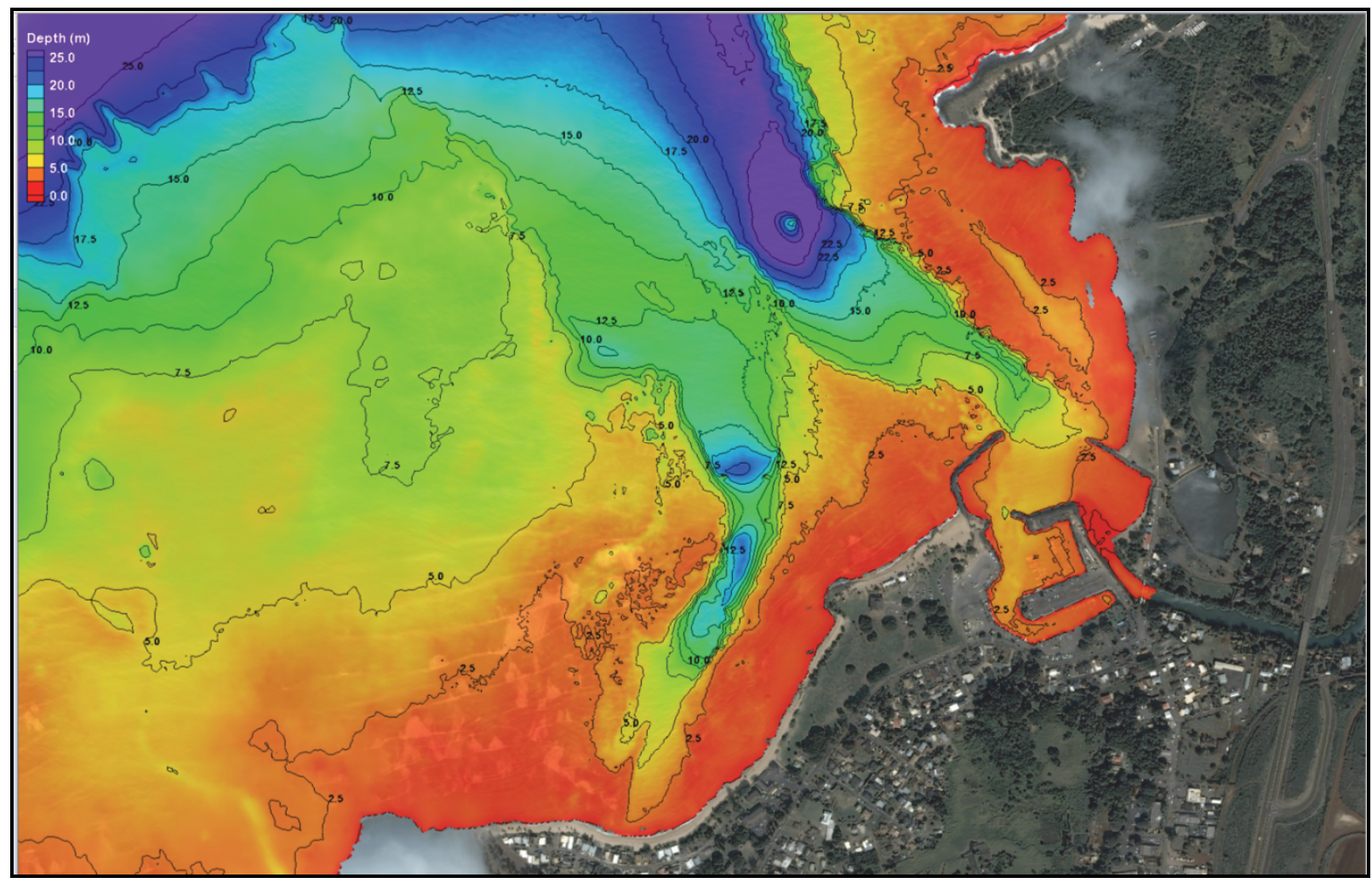

Figure 7. Bathymetry contours within the Haleiwa RSM Region (depth in meters, shown in $2.5 \mathrm{~m}$ contours).

Figure 8 shows the resulting water circulation patterns simulated from the $15 \mathrm{yr}$ return-period wave event. The general circulation patterns during a large wave event are dictated by the presence of the relic stream channels offshore of Kaiaka Beach and HSBH. The small black arrows in the figure indicate the direction of flow while current velocities are color coded in accordance with the legend in the top left corner of the figure (ranging from $0 \mathrm{~m} / \mathrm{sec}$ in blue to $2 \mathrm{~m} / \mathrm{sec}$ in red). The large black arrows represent the generalized current patterns of the region. Interpretation of the CMS-FLOW results suggest that flow enters the Kaiaka Beach channel from both the reef and the nearshore waters. Flow also enters the adjacent channel offshore of HSBH from the reef fronting Alii Beach and also from the Haleiwa Beach Park shoreline. A strong, shore-parallel current from left to right is evident in the vicinity of the harbor breakwater, emptying into the harbor channel. The simulation of the $2 \mathrm{yr}$ return-period event shows a similar circulation pattern, with slightly lower current magnitudes but almost identical current directions. 


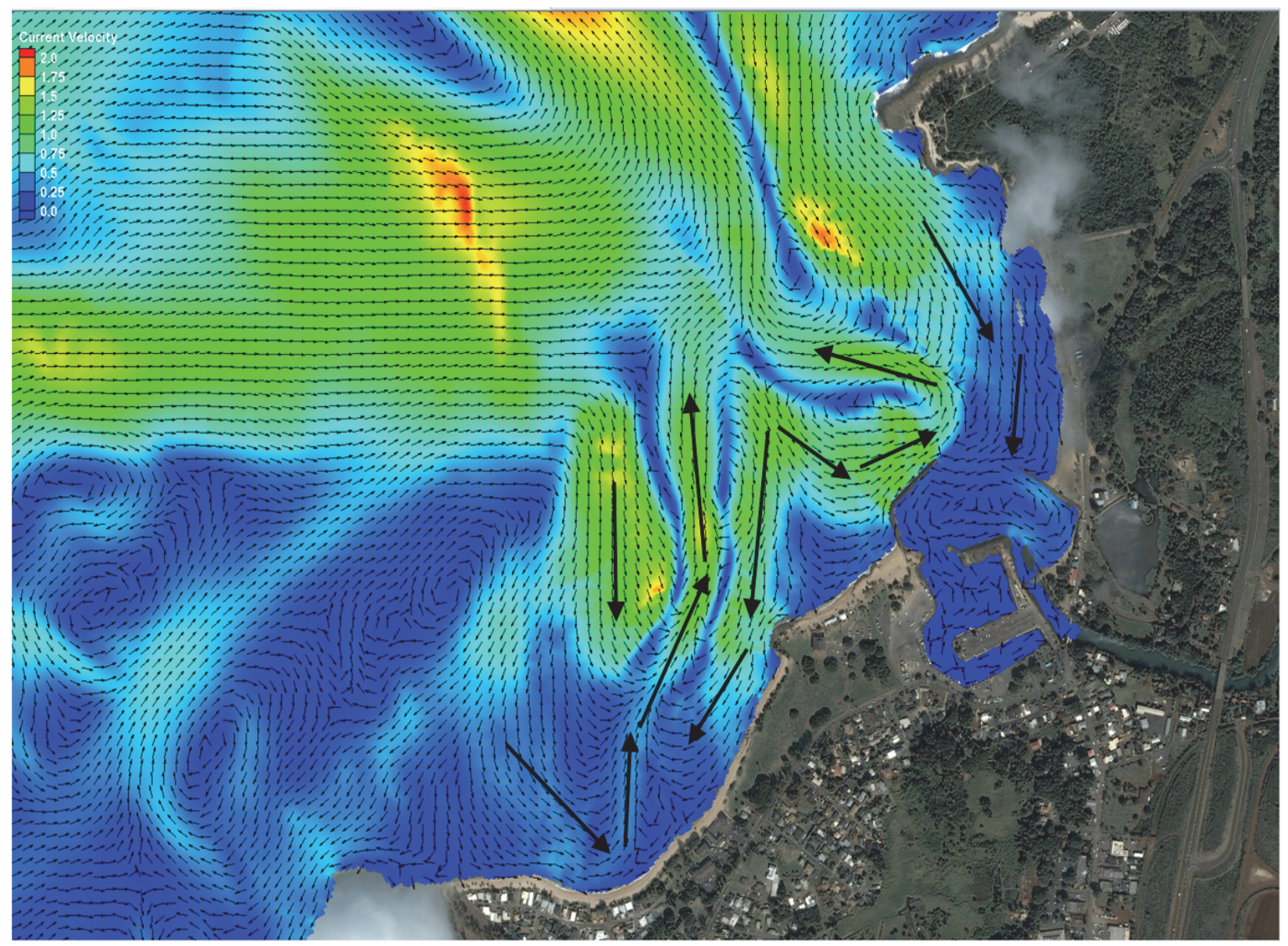

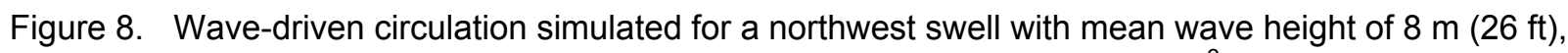
peak wave period between 16 and $22 \mathrm{sec}$, and wave direction of $320^{\circ}$.

The simulation of the trade wind sea case shows very weak circulation in the region. This is primarily because wind generated waves from ENE are almost parallel to the shoreline and do not refract efficiently into the region due to their shorter wave periods. Without a wavegenerated current, the small changes in water surface elevation due to tidal variations are not enough to generate currents in excess of $0.25 \mathrm{~m} / \mathrm{sec}$. This simulation of the mild trade wind condition was eliminated from further analysis as it is assumed that the resulting weak circulation is not sufficient to generate significant transport of sediment.

Although there exist no field measurement data to validate the results of these model simulations, the results are thought to be realistic based on knowledge of the area. Anecdotal evidence provided by surfers and paddlers familiar with the area is in agreement with the shoreparallel current near the harbor breakwater and offshore directed currents observed along both channels during large wave events. Alignment of the sandy shorelines driven by longshore sediment transport at both Haleiwa Beach and Alii Beach correspond well to the surf zone current directions shown in the model simulations.

The PTM provides powerful visualizations of potential sediment transport utilizing the results from both CMS-WAVE and CMS-FLOW. Figures 9a-f show the PTM solution for the $15 \mathrm{yr}$ 
event at $2 \mathrm{hr}$ intervals for the first $12 \mathrm{hr}$ of the simulation. Particles are color coded according to the littoral cell where they originate. Yellow particles originate in the Puaena Point cell, red in the Haleiwa Beach cell, green in the Alii Beach cell, light blue in the East Kaiaka Beach cell, and dark blue in the West Kaiaka Beach cell.

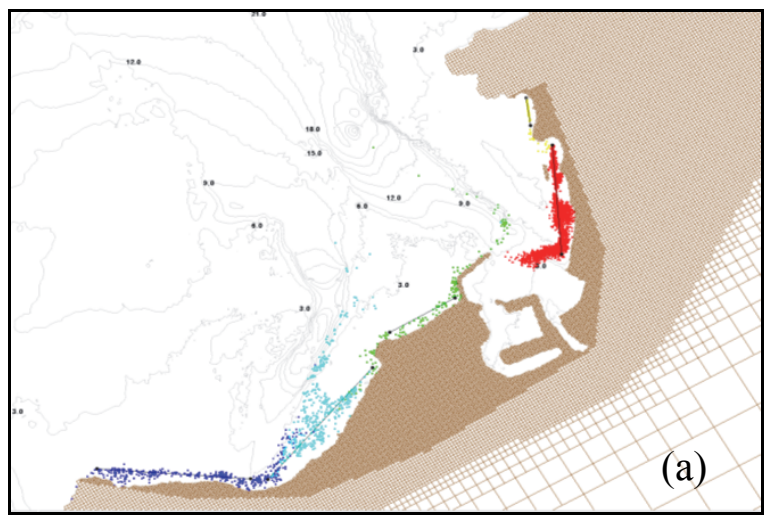

Figure 9a. After $+2 \mathrm{hr}$.

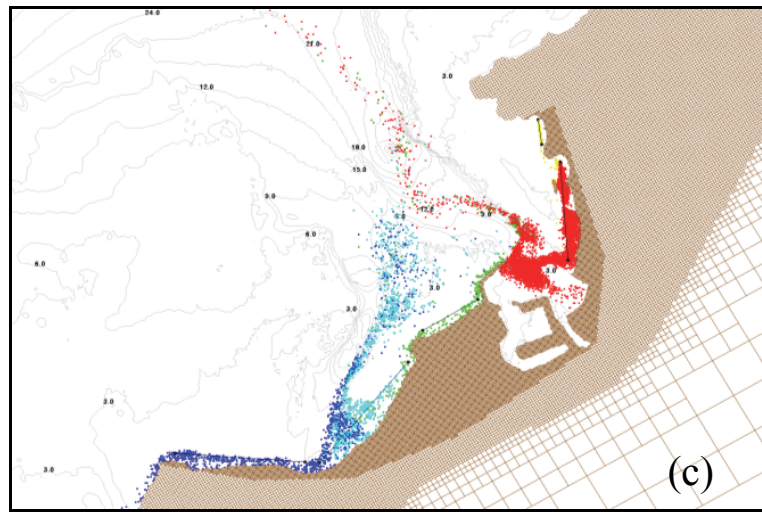

Figure 9c. After $+6 \mathrm{hr}$.

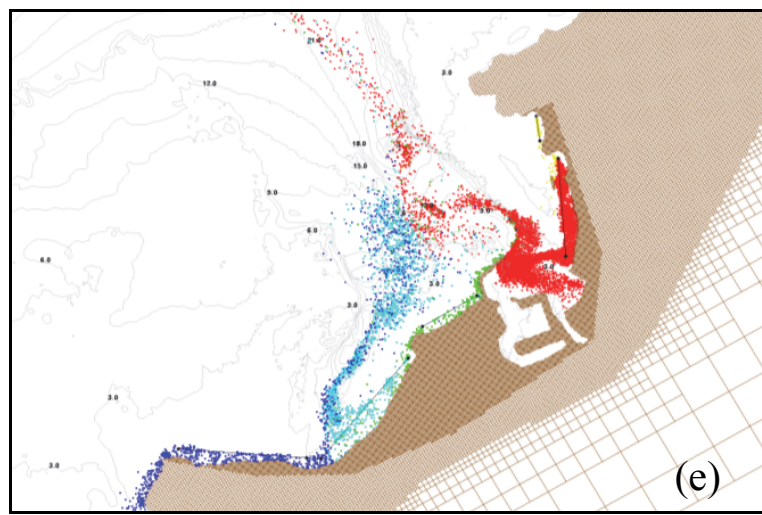

Figure 9e. After $+10 \mathrm{hr}$.

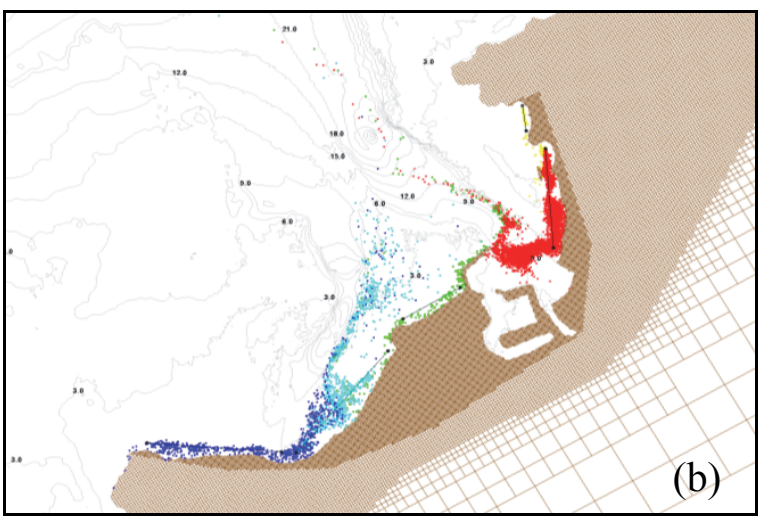

Figure 9b. After $+4 \mathrm{hr}$.

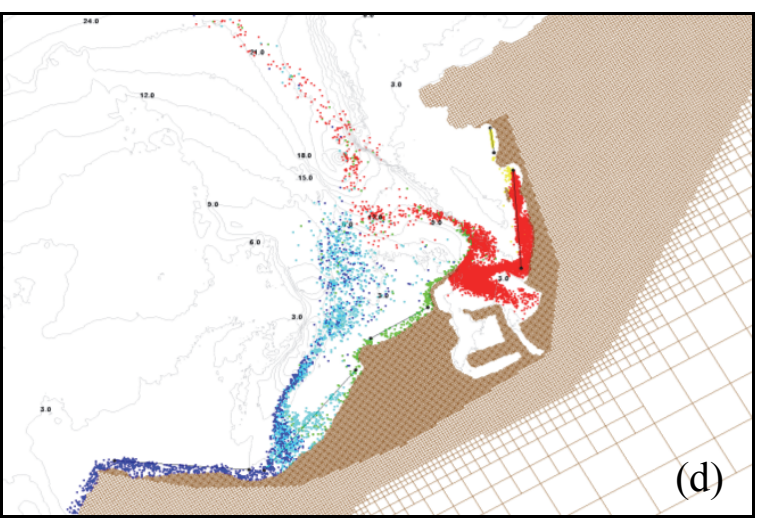

Figure $9 \mathrm{~d}$. After $+8 \mathrm{hr}$.

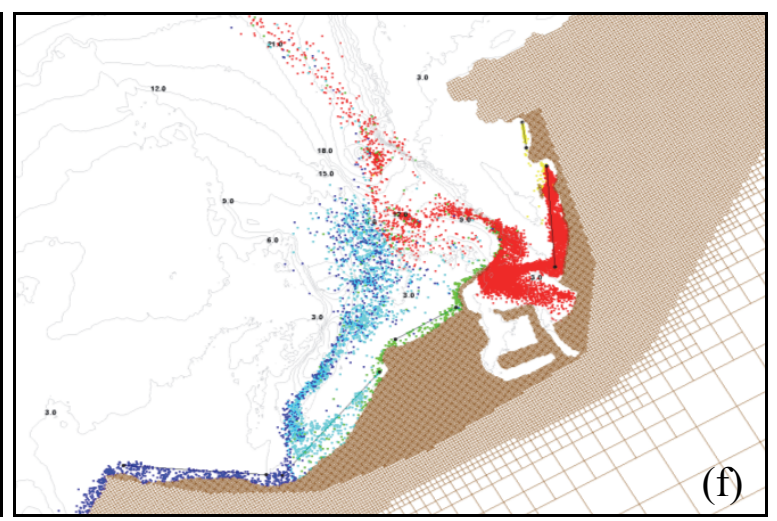

Figure 9f. After $+12 \mathrm{hr}$.

Figures 9a-f. Particle Tracking Model (PTM) results for transport of sand from Haleiwa Beach Park shoreline under northwest swell simulated by CMS-Wave and CMS-Flow over a $12 \mathrm{hr}$ time period. 
Results of the PTM indicate that during a large wave event, sediment is directed offshore by the currents flowing out of both channels. Sediment in both littoral cells that make up Kaiaka Beach (light and dark blue particles) are primarily directed by opposing longshore currents to the channel in the center of the beach where they then move offshore. This seems to be in agreement with the shoreline of Kaiaka Beach, which is relatively even in width along the entire bay and therefore does not indicate a strong longshore transport signal in a single direction. It appears that after these particles move out some distance into the channel, they begin to settle out onto the nearshore reef fronting Alii Beach. This may be due to incoming waves and resulting currents pushing them out of the channel and onto the reef in the breaker zone. This may provide a temporary storage area, allowing some of this material to return to the littoral zone after the large wave event is over or becomes less energetic. There is some indication of sediment transport from the West Kaiaka Beach cell toward the south and out of the region; however, it is assumed this is minimal as there is no evidence of this in aerial photos or in Kaiaka Bay to the west.

The particles in green that start on Alii Beach are directed east toward the harbor breakwater because of a strong, shore-parallel current in this area. There is no indication that this sediment is moved offshore or onto the nearshore reef until it reaches the harbor entrance channel. As mentioned, this result agrees well with the current observed by surfers during wave events as well as the shape of the fillet at the shoreline on Alii Beach (Figure 2) which shows much of the sediment in this cell piled up near the breakwater root.

The sediment that originates on Haleiwa Beach (red particles in Figures 9a-f) initially moves south toward the harbor (Figure 9a). This direction of transport agrees with the asymmetrical shape of the shoreline in this cell shown in Figure 2, where there is a relatively wide beach at the south end of the cell and a narrow and erosive beach at the north end of the Haleiwa Beach cell. A few more hours into the simulation, the particles diverge with some going into the harbor and some going offshore via the entrance channel. This seems reasonable given the overall erosive nature of this littoral cell (Figure 5) and the observance of calcareous sand in harbor dredge material and at the mouth of the Anahulu River. The sediment moving offshore in the channel appears to be partially dispersed over the nearshore reef, and the remainder moves offshore out of the nearshore region where it is likely lost from the littoral system of this region.

Finally, the sediment within the northernmost littoral cell at Puaena Point, represented by yellow particles in Figure 9, appears to be moving toward the south. The PTM indicates that sediment may be moving out of the cell and around the rocky headland that separates this cell from the Haleiwa Beach cell. This is an interesting result as it was previously assumed that this was a closed littoral cell. No sediment appears to be moving directly offshore, so movement around the headland to the Haleiwa Beach cell would support the observation that this cell has historically been slightly erosive (Figure 5).

SEDIMENT BUDGETS: The results of the wave/circulation model steering runs and the subsequent PTM visualization, in combination with the shoreline change analysis, were used to develop a conceptual regional sediment budget for the post-project condition. The pre-project sediment budget relied primarily on the shoreline change analysis using aerial photography from this time period, but with the underlying assumption that the primary circulation patterns in the region are similar to those of the post-project condition. This assumption was made because the morphology of the natural channels and nearshore reef system were minimally influenced by 
harbor construction. Following the procedures outlined in Rosati and Kraus (2001) and Dopsovic et al. (2002), sediment budgets were generated using SBAS for ArcGIS 10, with volumes of erosion/accretion for each cell determined from the calculated values shown in Figure 5. Transport quantities and directions were inferred from the results of wave/circulation modeling and the PTM results discussed in the previous section.

The pre-project regional sediment budget shown in Figure 10 encompasses five littoral cells: (a) Kaiaka Beach West, (b) Kaiaka Beach East, (c) Alii Beach, (d) Haleiwa Beach, and (e) Puaena Point, all of which are negative (slightly erosive) cells in accordance with the shoreline change and volume analysis. The Haleiwa Beach littoral cell extends along only part of the pre-harbor sandy shoreline because shoreline change analysis of this stretch of beach was only partially completed. This is because the construction of the harbor in 1966 removed the southern portion of the beach and, therefore, a complete data set over the entire period of analysis was not available. As previously mentioned, the sediment pathways are assumed to be similar (in direction though not necessarily magnitude) to those indicated by the PTM results of the post-project modeling and are also in agreement with visual observations of shorelines in the aerial photographs. There is not a great deal of sediment exchange between these cells, with most sediment going offshore into the channels or into the section of beach where no shoreline change data are available. Transport from the Puaena Point cell to the Haleiwa Beach cell is the exception.

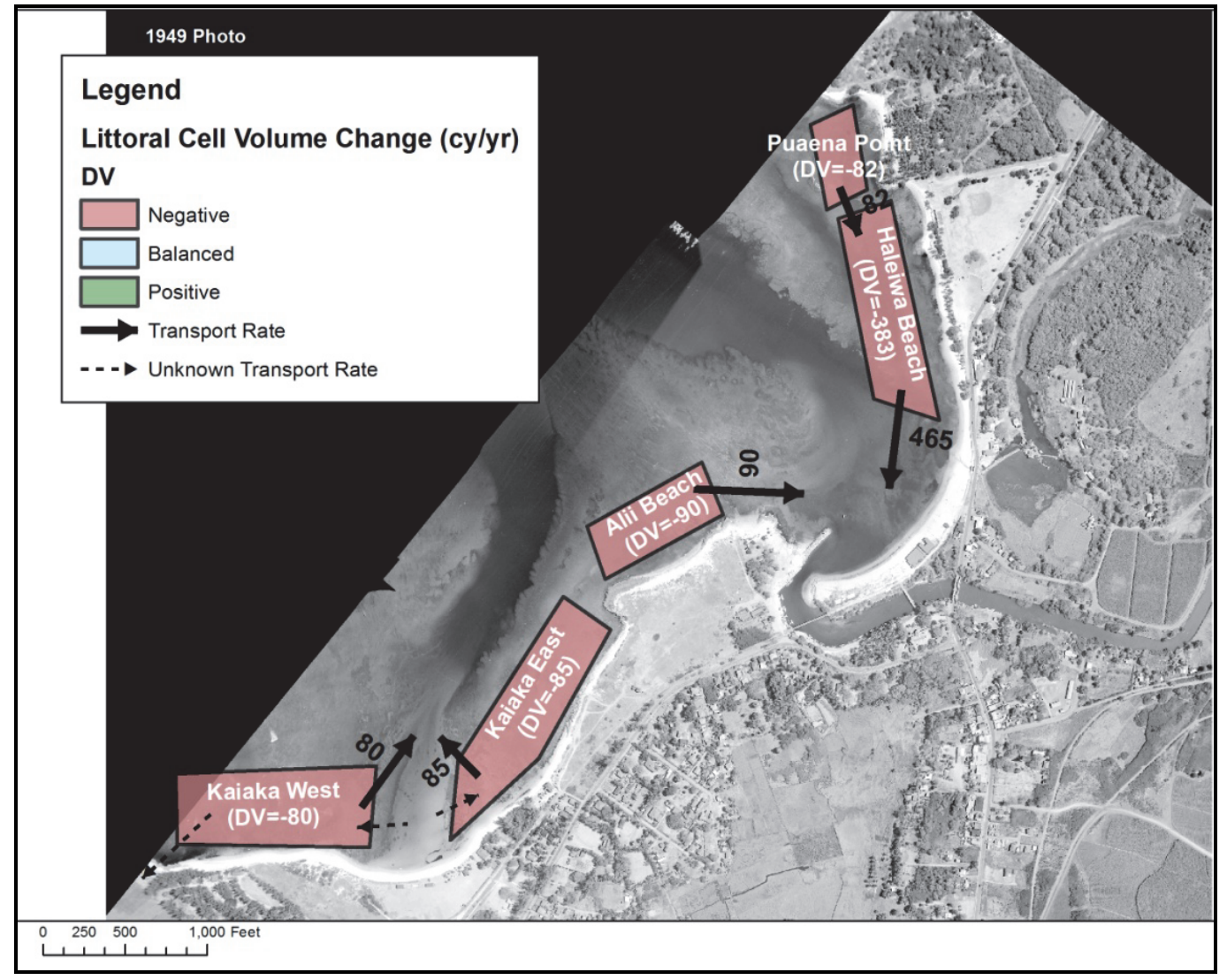

Figure 10. Pre-project (1928-1949) sediment budget for Haleiwa RSM Region. 
The post-project sediment budget in Figure 11 shows similar littoral cells to the pre-project budget but with an additional cell representing Haleiwa Harbor. The sediment pathways in the post-project budget are also similar to the pre-project condition but now indicate more exchange between cells with the addition of the harbor littoral cell. This sediment budget displays that the Puaena Point, Haleiwa Beach, and Alii Beach cells are still negative or erosive, though greater in magnitude than the pre-project condition. However, both Kaiaka Beach cells are stable in the post-project condition. This appears to indicate that, although large wave events may transport sand from these cells into the channel or out of the region (represented by the dashed arrows without transport rates in Figure 11), there is also a mechanism for transport back into the cells, which keeps them relatively stable. Additional studies are needed to quantify these rates.

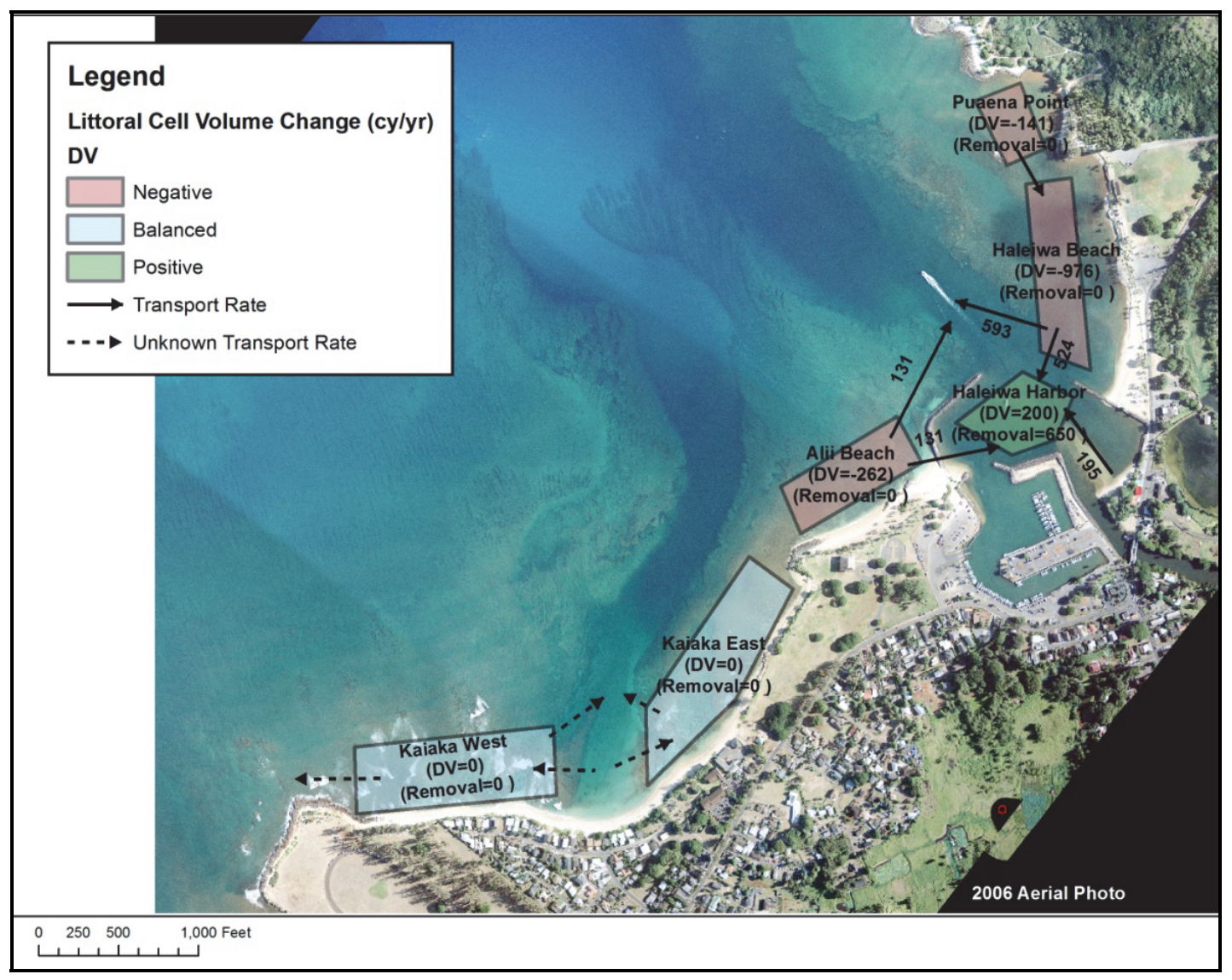

Figure 11. Post-project (1988-2006) sediment budget for Haleiwa RSM Region.

The Haleiwa Harbor cell is positive (accretive), being fed by sand transported from Alii Beach over the harbor breakwater root and from Haleiwa Beach through both the harbor channel and the permeable groin along this cell boundary. These instances of transport through structures are not conveniently modeled because they occur in the upper tidal region (beyond the capability of CMS-WAVE and CMS-FLOW), but have been observed upon inspections in the field. There is also a small, assumed transport from the Anahulu River since terrestrial sediments have been observed in dredged material. The harbor cell volume change is positive $(+200 \mathrm{cu} \mathrm{yd} / \mathrm{yr})$, even after factoring in removal by dredging of an average $650 \mathrm{cu} \mathrm{yd} / \mathrm{yr}$. 
CONCLUSIONS: The analysis of existing shoreline change data, field observations, and modeling results has enabled the development of pre- and post-HSBH sediment budgets that may help develop better informed decisions for future sediment management within the Haleiwa RSM region. Like all sediment budgets, these are based on some assumptions and engineering judgment and, therefore, subject to scrutiny. However, the information presented in this Coastal and Hydraulics Engineering Technical Note suggests the following conclusions:

- The Kaiaka Beach cells are relatively stable, likely due to an onshore/offshore exchange with the nearshore channel in this area, allowing it to act as a storage area. They do not have much (if any) interaction with other cells in the region. For these reasons, it is not likely that RSM activities would be needed in this part of the region.

- The Alii Beach cell is losing sand over the breakwater and into the harbor as well as along the outside of the breakwater and into the harbor entrance channel. A structural improvement at the root of the breakwater may reduce some of the erosion in this cell as well as reducing maintenance dredging requirements in the harbor channel.

- A portion of the sand from Alii Beach and Haleiwa Beach is being directed offshore into the channel at the harbor entrance, a phenomenon that may have been caused or amplified by the construction of Haleiwa Harbor. Some of this sand may be staying within the littoral system, but based on increased erosion rates in recent years, it is likely that some of this sand is being moved into deep water by the offshore current in the channel and is being lost from the system. It may be worthwhile to investigate whether any of this sand is residing in deeper areas of the channel and, thus, could be used as sand sources for the region.

- The remainder of sand leaving the Haleiwa Beach cell is ending up in the harbor channel in the lee of the breakwater and nearby areas. This is likely adding to the maintenance dredging requirement in the channel. Tightening the permeable groin at the south end of Haleiwa Beach and/or determining whether beach-quality sand can be recovered from areas adjacent to the harbor (near Anahulu Stream mouth) may be viable ways of reducing maintenance requirements.

- Nourishment of Haleiwa Beach could be used to address the erosion happening in this cell. However, the strong transport from north to south in this region, and the transport mechanisms out of the cell mentioned above, would require tightening of the permeable groin and construction of some form of new retention structures to aid in keeping the nourished sand within the cell.

- The Puaena Point cell may be losing some sand to Haleiwa Beach via transport around the headland that separates them; however, this cell is relatively stable, and it is not likely that RSM activities would be needed in this part of the region.

POINTS OF CONTACT: This Coastal and Hydraulics Engineering Technical Note was prepared as part of the USACE Regional Sediment Management Program, and was written by Jessica H. Podoski, US Army Corps of Engineers Honolulu District (POH), Honolulu, Hawaii, with input from the Hawaii RSM Product Delivery Team. Thomas D. Smith is the USACE Pacific Ocean Division (POD) RSM Point of Contact (POC). Additional information relevant to the Haleiwa Region projects has been developed by Smith (2014). Additional information 
pertaining to Hawaii RSM can be found at http://gis.poh.usace.army.mil/rsm/index.htm and at the RSM Program website http://rsm.usace.army.mil.

Questions concerning this CHETN or the USACE RSM Program may be addressed to the following:

Jessica H. Podoski

Jessica.H.Podoski@usace.army.mil

(POH Coastal Engineer)

Thomas D. Smith

Thomas.D.Smith@usace.army.mil

(POD RSM POC)

Linda S. Lillycrop

Linda.S.Lillycrop@,usace.army.mil

(USACE RSM Program Manager)

This US Army Engineer Research and Development Center (ERDC), Coastal and Hydraulics Laboratory (CHL), CHETN should be cited as follows:

Podoski, J. H. 2014. Hawaii RSM: Regional sediment budgets for the Haleiwa Region, Oahu, HI. ERDC/CHL CHETN-XIV-38. Vicksburg, MS: US Army Engineer Research and Development Center.

\section{REFERENCES}

Bouws, E., H. Gunther, W. Rosenthal, and C. L. Vincent. 1985. Similarity of the wind wave spectrum in finite depth water: Part I-Spectral form. Journal of Geophysical Research. 90(C1):975-986.

Dopsovic, R., L. Hardegree, and J. D. Rosati. 2002 (rev. 2003). Sediment Budget Analysis System-A: SBAS-A for ArcView $^{\circ}$ application. ERDC/CHL CHETN-XIV-7. Vicksburg, MS: US Army Engineer Research and Development Center. http://chl.erdc.usace.army.mil/library/publications/chetn/pdf/chetn-xiv-7.pdf

Fletcher, C. H., B. M Romine, A. S. Genz, M. M. Barbee, M. Dyer, T. R. Anderson, S. C. Lim, S. Vitousek, C. Bochicchio, and B. M Richmond. 2012. National assessment of shoreline change: Historical shoreline change in the Hawaiian Islands. Open-File Report 2011-1051. Santa Cruz, CA: US Department of the Interior, US Geological Survey, Pacific Coastal and Marine Science Center. http://pubs.usgs.gov/of/2011/1051/pdff ofr2011-1051 report_508 rev052512.pdf

Hwang, D. J. 1981. Beach changes on Oahu as revealed by aerial photographs: Honolulu, Hawaii. Technical Supplement 22. Honolulu, HI: State of Hawaii, Department of Planning and Economic Development, Coastal Zone Management Program.

McDonald, N. J., M. H. Davies, A. K. Zundel, J. D. Howlett, Z. Demirbileck, J. Z. Gailani, T. C. Lackey, and J. Smith. 2006. PTM: Particle Tracking Model; Report 1, model theory, implementation, and example applications. ERDC/CHL TR-06-20. Vicksburg, MS: US Army Engineer Research and Development Center.

Rosati, J., and N. Kraus. 2001 (rev. 2003). Sediment Budget Analysis System (SBAS): Upgrade for regional applications. ERDC/CHL CHETN-XIV-3. Vicksburg, MS: US Army Engineer Research and Development Center. http://chl.erdc.usace.army.mil/library/publications/chetn/pdf/chetn-xiv-3.pdf 
Sanchez, A., W. Wu, T. M. Beck, H. Li, J. Rosati, R. Thomas, J. D. Rosati, Z. Demirbilek, M. Brown, and C. Reed. 2011. Validation of the Coastal Modeling System; Report III, hydrodynamics. ERDC/CHL TR-11-10. Vicksburg, MS: US Army Engineer Research and Development Center.

Sea Engineering, Inc. 1988. Oahu shoreline study. Honolulu, HI: City and County of Honolulu, Department of Land Utilization.

Smith, T. D. 2014. Potential regional sediment management (RSM) projects in the Haleiwa Region, Oahu, HI. ERDC/CHL CHETN-XIV-37. Vicksburg, MS: US Army Engineer Research and Development Center.

NOTE: The contents of this technical note are not to be used for advertising, publication, or promotional purposes. Citation of trade names does not constitute an official endorsement or approval of the use of such products. 